\title{
Earning Management Practices within ERP Environment: A Case Study of ERP's Companies Listed in Amman Stock Exchange
}

\author{
Faculty of Accounting and Accounting Information Systems Departments \\ Al-Balqa Applied University \\ Al-Salt, JORDAN \\ SAQER AL-TAHAT \\ Faculty of Economics and Administrative Sciences \\ $\mathrm{Al}$ al-Bayt University \\ Al-Mafraq, JORDAN
}

SULAIMAN WESHAH, MOHAMMAD ELESSA, AYMAN SHANTI, RAFAT SALAMEH

\begin{abstract}
The present study aims to explore if the earning management practices differ for companies adopted Enterprise Resources Planning (ERP) systems within three categories (Bank and Insurance, Services, and Manufacturing) companies of listed (ERP)'s companies in Amman Stock Exchange (ASE). Therefore, their financial statements from 2012 to 2019 have been analysed depending on modified Jones model (1995). The study revealed that there is a positive relationship between (ERP)'s manufacturing sector companies with earning management practices, while there is no statistically significant correlation between the (ERP)'s services sector companies, (ERP)'s bank and insurance sector companies with earning management. Also, it doesn't matter of adopting ERP systems to be engaged or not with earning management practices. Therefore, the study recommends users of manufacturing companies' financial statement to focus on the increase inside financial statements of manufacturing sector.
\end{abstract}

Key-Words: - Earnings Management, ERPs Manufacturing Companies, ERPs Services Companies, ERPs Banks \& Insurance Companies, Amman Stock Exchange (ASE), Jordan.

Received: March 11, 2021. Revised: April 24, 2021. Accepted: May 4, 2021. Published: May 10, 2021.

\section{Introduction and Background Material}

Management may tend to manipulate the profits of the company by manipulates its financial reports so that appeared in a way serves their own interests, and as a result of these behaviors came the theory of the agency to limit the behavior of the management that puts its interests and objectives before the interests and objectives of the company, and this led to the emergence of many actions such as Earning management, Income smoothing, Creative Accounting and Aggressive Accounting.

The administrative and accounting systems in companies have been affected by the rapid successive developments in the world of information technology and electronic computer systems [24]. Also, the process of electronically processing data has become necessary in large and small enterprises that aim to achieve greater efficiency in their activities, due to the diversity of information that companies need in their business in addition to the diversity of their production tools [20].

In an enterprise resource planning system (ERP), the operational and financial systems are linked to each other through a complex information flow, where the databases are managed within the company in what is known as the Data Bases Management System DBMS, [3] who also mentioned that building and preparing an (ERP) system may face difficulties due to the need for radical changes in the company that seeks to implement the system, and thus resistance to this change that may occur by company employees.

The (ERP) systems reached a new level of automation and integration of corporate operations, especially in eliminating and eliminating unjustified verbosity and inefficiencies in traditional systems [26]. In addition, 
(ERP) systems helping to unleash the true potential of companies by integrating business and management processes, managers at different levels in an organization to access reports and summaries prepared on basic actions of organization through the information stored inside the system [25].

Earning management is the selection of accounting policies or procedures that affect profit so that departments can achieve certain targeted profits that are disclosed in the financial statements [21] and [28] clarified that there are three classifications for earning management (white, gray and black), and the management of white earning means that managers can choose accounting treatments flexibly and show their own information related to cash flows from future operating activities, as for the management of gray earning, it can be defined as the selected accounting transactions that contribute to increasing the interests of the managements, while the management of black earning reflects tricks that used by management to distort or reduce the transparency of financial reporting. [8] mentioned that management can manipulate earnings management by affecting real activity decisions too.

By defining the concept of earning management practices, the management seeks, through these practices, to achieve many objectives, including: Increase the value of profits for the purposes of satisfying shareholders and capital owners, raising the value of profits for the purpose of obtaining loans from lenders and suppliers, as well as obtaining credit facilities, reducing profits for the purpose of income tax evasion, and [2] added it may be used to increase the management's share of incentives and rewards.

The following methods and measures are used to reveal earning management practices, as follows, depending on [18], [13], [19], [24], [3], [9], [2], [15], [23] and [8]:

Receivables analysis method and Jones Model (1991) [11], whereby optional receivables are estimated by the following equation:

$$
\begin{aligned}
& \text { NDTACCi, t =ã1(1/TAt, i-1) + ã2( } \triangle \text { REVi, t } \\
& \text { / TAi, t })+\tilde{a} 3(\text { PPEi, } t / \text { TAi, t })
\end{aligned}
$$

NDTACCi,t: Non-Discretionary Accruals in company i for year $t$.

$\triangle \mathrm{REVi}, \mathrm{t}$ : Change in the revenue of firm i during year t.
PPEi,t: Value of real estate, property and machinery in company $i$ for year $t$.

TAi,t: $=$ Total assets in company $\mathrm{i}$ for year $\mathrm{t}$.

To determine the value of the coefficients ã1, ã2, ã3, the method of least squares is used using the following slope equation:

$$
\begin{aligned}
& \text { TACCi, } \mathrm{t}=\alpha 1(1 \div \text { TAi, } \mathrm{t}-1)+\alpha 2(\Delta \text { REVi, } \mathrm{t} \\
& \div \text { TAi, } \mathrm{t}-1)+\alpha 3(\mathrm{PPEi}, \mathrm{t} \div \mathrm{TAi}, \mathrm{t})+\varepsilon
\end{aligned}
$$

Where:

TACCi, $\mathrm{t}:=$ Total Discretionary Accruals in company $i$ for year $t$.

Receivables analysis method and the modified Jones Model (1995) [12], and it is one of the most powerful models used to measure earning management, so that total receivables are measured by measuring the cash flow, so that the net is extracted between net operating income and operating cash flow, and as in the equation:

TACCi, $\mathrm{t}=\mathrm{ONIi}, \mathrm{t}-\mathrm{OCFi}, \mathrm{t}$

Where:

TACCi, t: Total Discretionary Accruals in company i for year $\mathrm{t}$.

ONIi, t: Net operating profit at company i for year $\mathrm{t}$.

OCFi, t: Net operating cash flow in company i for year t.

Then the value of the optional benefits is calculated through the following regression equation:

TACCi, $\quad \mathrm{t} \div \mathrm{TAi}, \quad \mathrm{t}-1=\alpha 1(1 \div \mathrm{TAi}, \quad \mathrm{t}-1)$

$+\alpha 2(\triangle \mathrm{REVi}, \mathrm{t}-\Delta \mathrm{RECi}, \mathrm{t} \div \mathrm{TAi}, \mathrm{t}-1)+\alpha 3(\mathrm{PPEi}$,

$\mathrm{t} \div \mathrm{TA}$ i, $\mathrm{t}-1)+\alpha 4$ ROAi, $\mathrm{t}-1+\varepsilon$

Where:

$\triangle \mathrm{RECi}, \mathrm{t}$ : Change in accounts in progress in firm $\mathrm{i}$ for year $\mathrm{t}$.

PPEi, t: Value of real estate, property and machinery in company $i$ for year $t$.

ROAi, $\mathrm{t}-1$ : Return on assets in firm i for year $\mathrm{t}$. 
To determine the value of the coefficients $\alpha 1, \alpha 2, \alpha 3$, and $\alpha 4$, the method of least squares is used using the following slope equation:

$$
\begin{aligned}
& \text { NDTACCi, } \mathrm{t} \div \text { TAi, } \mathrm{t}=\tilde{\mathrm{a}} 1(1 \div \mathrm{TAt}, \mathrm{i}-1)+\tilde{\mathrm{a}} 2 \\
& (\triangle \mathrm{REVi}, \mathrm{t}-\triangle \mathrm{RECi}, \mathrm{t} \div \mathrm{TAi}, \mathrm{t}-1)+\tilde{\mathrm{a}} 3(\text { PPEi, } \mathrm{t} \\
& \div \text { TAi, } \mathrm{t}-1)+\tilde{\mathrm{a}} 4 \text { ROAi, } \mathrm{t}-1+\varepsilon
\end{aligned}
$$

And then the value of the Discretionary Accruals is calculated by calculating the difference between:

$$
\begin{aligned}
& \text { DACCi, } \mathrm{t}=\text { TACCi, } \mathrm{t} \div \text { ATi, } \mathrm{t}-1-\mathrm{NDTACC} i, \mathrm{t} \div \\
& \text { TAi, } \mathrm{t}-1
\end{aligned}
$$

Then the average value of the discretionary accruals is calculated in the company over the years, so that the presence of any fluctuation in the value will give an indication of the existence of earning management practices, while if there is no fluctuation and stability in the value, this is evidence that there are no earning management practices in the company. It should be noted that the previous methods of measurement are based on Qualitative Measurement for earning management.

Although both [5] and [7] concluded that there is no effect of discretionary entitlements as one of the methods of earning management practices on market power or market value within their studied filed in China and Indonesia. We believe, through the previous review of measurement methods and disclosure of earning management, that the modified Jones' method and scale is the most used and widespread, because it is one of the least defective models, which will be adopted in this study to measure earning management in ERP companies within their different sectors (Banks $\&$ Insurance, Services and Manufacturing).

\section{Problem Formulation}

Earning management with its various methods is one of the most important means used by joint-stock companies at the present time to distort accounting results and show them in a way that serves the interests of these companies 'administrations, and unites many incentives and motives that may lead to the practice of earning management. There are many investors, shareholders, and other parties whose decisions depend largely on the company's market performance within the financial market, which generates incentives for corporate departments to earning management and show the company's results in a manner consistent with the expectations of these parties, especially if the many problems and difficulties that these markets faced are known in a way. A year after the successive global financial crisis, the most recent of which was in 2008. In addition, currently within Corona virus (Covid-19) pandemic which resulting in a worldwide economic recession [1] may lead companies going to use earning management practices to get the needed impact.

The present study aims to explore if the earning management practices differ for companies adopted Enterprise Resources Planning (ERP) systems within three categories (Bank and Insurance, Services, and Manufacturing) companies of listed (ERP)'s companies in Amman Stock Exchange (ASE) and differs from previous studies by trying to measure if there is impact of using ERP System's on earning management practices.

\subsection{ERP Systems' Status in Jordanian Listed Companies}

After conducting a survey of the establishments listed on the Amman Stock Exchange, which reached to 282, the number of companies applying the ERP system was 55 , with a percentage of $19.5 \%$ of the total companies listed on the Amman Stock Exchange. It is noticed that the implementation rate of the ERP system is relatively low, and this may be due to the cost of implementing the system and the costs associated with training its users in addition to the costs of protection needed for the system.

(See Appendix 1 which illustrates the listed ERP's Companies in ASE classifies by sector)

\section{Problem Solution}

\subsection{Research Methodology and Research Tools}

To reach the objectives of the study, the researchers used the analytical descriptive approach to measure the level of earning management practices in companies that have ERP systems and are listed on the Amman Stock Exchange, and the researchers used a set of tests, such as the One Sample T-test, and the Distribution Test Normal variables, and also use the linear correlation test, to ensure that there is no high correlation between the independent variables, and to make sure that there are no variance problems, the Breusch-Pagan Cook-Weisberg test was used, and then the F-test, Breuch \& Pagan tests were used to test the data. The study objectives were achieved, and the tests were applied through the (E-Views) program. The most important statistical indicators that are necessary for the judgment to suit the used model and its explanatory power were extracted, such as the value 
of $t$, the Fisher distribution of $F$, Adjusted $\mathrm{R}^{2}$, the corrected determination coefficient, which are used for judgment On the absence or existence of a relationship between the variables, and reaching the results of the study for each sector using ERP systems inside Jordan economy.

There are many ways to measure earning management practices, such as Healy (1985), Jones model (1991) [11] and Jones modified model (1995) [12] which are quantitative measurements by estimating discretionary accruals and explanatory variables respectively [17] and [14]. Other measures depended on qualitative analysis. This study depends on Jones modified model (1995) because It is one of the most powerful models used to measure earning management, so that total receivables, the cash flow are measuring, so that the net is extracted between the net operating income and the operating cash flow [9].

\subsubsection{Regression Model}

The model for measuring the relationship between companies using ERP systems in different sectors (Banks and Insurance, Service, Manufacturing) with earning management, and the following equation represents this model:

$$
\text { DACCi, } \mathrm{t}=\alpha 0+\beta 1 \text { BanInsi, } \mathrm{t}+\beta 2 \text { Servi, } \mathrm{t}+
$$$$
\beta 3 \text { Manui, } \mathrm{t}+\beta 4 \text { LNSizei, } \mathrm{t}+\beta 5 \mathrm{CFO} / \mathrm{TAi}, \mathrm{t}+\varepsilon
$$

\subsubsection{Dependent Variable}

DACCi, t: Discretionary Accruals As a guide and indicator of earning management practices.

\subsubsection{Independent Variable}

BanInsi, t: Banks and Insurance sector companies that are using ERP systems

Servi, t: Services sector companies that are using ERP systems

Manui, t: Manufacturing sector companies that are using ERP systems

LNSizei,t: Company size, the measurement of this variable based on taking the natural logarithm of total assets, as this measure is the most commonly used and common in previous studies, and given that the larger the size of the company, where the larger size of the company will attract analysts, investors and financiers, so management of these companies use earning management practices [2].

CFO/TAi,t: The measurement of this variable was based on the division of net operating cash flows on total assets, indicated that there are differences in the results of previous studies in the form of the relationship between earning management and operating cash flow, as the results of the majority of these studies had a negative relationship. Between earning management and cash flows, in other words, the higher the level of cash flows, the more there is a decrease in earning management and vice versa, and the reason behind these practices is to raise the declared profits to cover the problems in cash liquidity [2].

Table 1: The coefficient of variance amplification and the permissible coefficient of variance for the study variables

$\begin{array}{lll}\begin{array}{lll}\text { Independent Variables } \\ \text { (Users of ERP Systems) }\end{array} & \text { Tolerance } & \text { VIF } \\ \text { Banks and Insurance sector } & 0.88 & 1.13 \\ \text { Services sector } & 0.81 & 1.23 \\ \text { Manufacturing sector } & 0.90 & 1.11\end{array}$

Table 2: Durbin Watson Test

Model D-W

Relation between banks and insurance sector 1.46 with earning management

Relation between services sector with earning 1.44 management

Relation between manufacturing sector with 1.45 earning management

Relation between banks and insurance sector, services sector, manufacturing sector, company size and cash flows on total assets with earning management

Table 3: Descriptive statistics of variables

$\begin{array}{ccccc}\text { Variables } & \text { Avg. } & \text { Std } & \text { L.Value } & \text { H. Value } \\ \text { Banks \& } & 1.64 & 0.53 & 1 & 3\end{array}$


Ins. Sec.

$\begin{array}{lllll}\text { Serv. } & 6.1006 & 1.0567 & 2.1527 & 8.5298 \\ \text { Sec. } & & & & \\ \text { Mfg. Sec. } & 2.4213 & 4.6366 & 0.13 & 46.51 \\ \text { Assets Size } & 7.444 & 0.5359 & 6.389 & 9.0833 \\ \text { Op. CF } & 0.0511 & 0.0949 & -0.2322 & 0.3766 \\ \begin{array}{l}\text { Earning } \\ \text { Mgt. }\end{array} & 0.0062 & 0.0900 & -0.403 & 0.408 \\ \text { (Disc. } & & & & \\ \text { Accruals) } & & & & \end{array}$

Table 4: Least Squares for Dependent Variable (DACC)

Std.

Variable Coefficient Error t-Statistic Prob.

Bank \&

$\begin{array}{lllll}\text { Ins. Sec. } & 0.0030 & 0.0033 & 0.89968 & 0.328 \\ \text { Serv. Sec. } & 0.0033 & 0.0034 & 0.96836 & 0.334 \\ \text { Mfg. Sec. } & 0.0047 & 0.0009 & 5.22522 & 0.000\end{array}$

LOG_TOTAL_

$\begin{array}{lllll}\text { ASSETS } & -0.0190 & 0.0076 & -2.49483 & 0.013 \\ \text { CFO_TAI_ } & & & & \\ \text { T_I_T } & -0.7399 & 0.0377 & -19.6163 & 0.000 \\ \text { C } & 0.1540 & 0.0558 & 2.76135 & 0.006 \\ \text { R }^{2} & 0.5587 & \text { Mean dependent var } & 0.006 \\ \text { Adjusted R } & 0.5530 & \text { S.D. dependent var } & 0.090 \\ \text { S.E. of } & & & \end{array}$

Regression $\quad 0.0602 \quad$ Durbin-Watson $\quad 1.032$

Sum squared

resid.

1.1224

Log likelihood $\quad 440.882$
(F-statistic) $\quad 98.1152$

Prob (F-

statistic) $\quad 0.0000$

\section{Conclusion}

It is noticed from Table (2) that the values of the VIF test for all independent variables is less than (10), while the value of the Tolerance Coefficient for all independent variables is greater than (0.05) and therefore there is no problem. High correlation between variables of the independent study, and this enhances their usability in the model.

(Durbin Watson) test to ensure that there are no problems in the statistical models of time series. This problem has a high impact on the efficiency of the regression model, and therefore on the accuracy and validity of the results, as the results of this test range between (0-4), and the closer the result of this test From number (2), the higher the autocorrelation intensity in the regression model [10].

It is clear to us from Table (3) that all the values were within the limits 0-4 and were close to (2) from the optimal value, and this indicates that there is no selfcorrelation problem in the models used in the study. In addition, the mean of earning management represented by optional benefits during the study period was 0.0062 , and the highest and lowest values for the variable were between 0.408 and 0.403 , and the standard deviation was 0.0900 .

Also, it is noted from the table (4) that the value of F $=98.1152$ has an important statistical value at the level of 0.05 , so there is a relationship of important statistical value, indicating the existence of a relationship between using ERP and earning management.

Depending on $\mathrm{R}^{2}$ it indicates there is $55 \%$ of change in earning management is due to use ERP systems in different sectors. [16] concluded that some companies use earning management practices to increase their profits, and this is reflected positively on the closing price of the share. Also, $\mathrm{R}^{2}$ it indicates that the model predicts the dependent variable in a good way.

It can be observed that the value of $\mathrm{t}=0.96836$ (Services Sector) and $t=0.89968$ (Bank and Insurance Sector) is not of significant statistical value at the level of 0.05 , and there is no statistically significant 
correlation between the Services sector and Bank and Insurance sector with earning management, and this result confirms the significant value of Prob $=0.334$ (Services Sector) and Prob $=0.328$ (Banks and Insurance Sector) which is higher from 0.05. This may relate to the simple data inside financial statements for services sector and the strong control on banks and insurance sector.

The coefficient of $\beta 3$ was positive, indicating that there is a positive relationship between ERPs' systems' manufacturing sector and earning management practices. This may relate to sophisticated data inside financial statements for manufacturing sector which make it easier to use earning management practices inside. This result confirmed by the significance value, which is equal to Prob $=0.00$, which is less than 0.05 .

In addition, if the coefficient of $\beta 4$ is negative, It means that the greater the size of the company, the less earning management was practiced, and this gives an indication that the larger the size of the company, the less the need to practice earning management, and in the viewpoint of the researchers, this result is logical, as companies with a small size have a motivation of earning management practices. Also, if $\beta 4$ is negative, it means that the lower of cash flow the higher earning management practices, where companies that have low cash flows are motivated to use the earning management practices due to the good presentation of the company's financial position in front of external parties.

There are researchers such as [22] in UK and [27] in Malaysia agreed that manufacturing sector engaged with earning management practices. But [13] revealed that industry classification does not explain the variance in earnings management activities for the selected sample.

Therefore, that led us to conclude it doesn't matter of adopting ERP systems to be engaged or not with earning management practices.

\section{Recommendations}

In view of the positive relationship between the manufacturing sector and earning management, manufacturing companies must be required to make additional explanations about the unjustified increase and their financial statement users should focus on the increase inside financial statements of manufacturing sector.
More penalties by official bodies and institutions such as the Securities Commission should take a place to limit and reduce earning management operations, in parallel they need to hold sessions and conferences to familiarize users of financial statements about earning management practices and their impact on their investment and lending decisions.

\section{Acknowledgment}

We would thank ASE employees for their coordinating to provide all needed financial statements related to listed ERP Companies within all sectors (Banks and Insurance, Service, Manufacturing) for the period from 2012 to 2019.

\section{References:}

[1] Adžić, Slobodan and Al-Mansour, Jarrah (2021). Business analysis in the times of COVID-19: Empirical testing of the contemporary academic findings, Management Science Letters,11(1), pp 1-10. doi: $10.5267 /$ j.msl.2020.8.036

[2] Abu Jubba, Muhammad, and Ali AlThunaibat (2017). The Impact of Profitability on Earning management in the Industrial Companies Listed in the Amman Financial Market, The Jordanian Journal of Business Administration, Volume 13, Issue 2, 259-280.

[3] Al-Taher, Asmahan Majid and Al-Khafaf, Maha Mahdi (2011). Introduction to management information systems. First Edition, Wael Publishing House, Amman, Jordan.

[4] Al-Tal, Heba (2015), The Impact of Profits Management on the Market Prices of Shares, a Test Study on Jordanian Engineering and Construction Companies, Unpublished Master Thesis, Middle East University, Amman, Jordan.

[5] Chang, H.-Y., Liang, L.-H. and Yu, H.-F. (2019), "Market power, competition and earnings management: accrual-based activities", Journal of Financial Economic Policy, Vol. 11 No. 3, pp. 368-384. https://doi.org/10.1108/JFEP-08-2018-0108

[6] Chen, Tianran (2010). Analysis on accrualbased models in detecting earnings management, Lingnan Journal of Banking, 
Finance and Economics, Lingnan University, 2

https://commons.ln.edu.hk/ljbfe/vol2/iss1/5

[7] Darmawan, I Putu Edi; T, Sutrisno and Mardiati, Endang (2019). Accrual Earnings Management and Real Earnings Management: Increase or Destroy Firm Value? International Journal of Multicultural and Multireligious Understanding, 6 (2), pp 8-19. DOI: 10.18415/ijmmu.v6i2.551

[8] Debnath, Nitai Chandra; Patnaik, B.C.M and Satpathy, Ipseeta (2019). Female directorship and real earnings management in Bangladesh: Towards an analytical assessment, 9 (11), pp 1723-1740. doi: 10.5267/j.msl.2019.6.018

[9] Enomoto, Masahiro; Kimura, Fumihiko and Yamaguchi, Tomoyasu (2015). Accrual-based and real earnings management: An international comparison for investor protection, Journal of Contemporary Accounting \& Economics, 11 (3), pp 183-198. https://doi.org/10.1016/j.jcae.2015.07.001.

[10] Gujarati, D.N., (2003), Basic econometrics, 4th edition. The McGraw-Hill Company, U.S.A.

[11] Jones, Jenifer J (1991). Earnings Management During Import Relief Investigations. Journal of Accounting Research. Oxford, 29 (2), pp 193-228.

[12] Jones, Jenifer J (1997). conservatism principle and the asymmetric timeliness of earnings. Journal of Accounting and Economics. New York, 24 (1), pp 3-37. https://doi.org/10.2307/2491047

[13] J. Toniato, J.E.F. Almeida, F. Moraes (2006), Earnings management and industry classification in Brazil: An exploratory investigation. Corporate Ownership and Control 3, pp 144-149. DOI: 10.22495/cocv3i1c1p3.

[14] Kantudu, Aliyu Suleiman \& Gololo, Ibrahim Aliyu (2020). Corporate Social Responsibility and Earnings Management: Measurement Approach Review, Journal of Accounting Research, Organization and Economics, 3 (2), pp. 182-195.
[15]

Lee, B. Brian and Vetter, William (2015). Critical Evaluation of Accrual Models in Earnings Management Studies, Journal of Accounting and Finance, 15 (1), pp 62-71.

[16] Lozi, Khalid Mohammad (2013). The Impact of Earnings Management Practice on Stock Prices Test Study on Joint Stock Industrial Companies Listed on the Amman Stock Exchange, Unpublished Master Thesis, Middle East University, Amman, Jordan.

[17] Marai, Awidat, \& Pavlovic, Vladan, (2014). An overview of earnings management measurement approaches: Development and evaluation. Journal of Economics and Organization, 11 (1), 21-36

[18] Mohanram, P. (2003). How to Manage Earnings Management. Accounting World, Institute of Chartered Financial Analysts of India, 1-11.

[19] Paulo, Edilson and Martins, Eliseu (2009). A Theoretical and Empirical Analysis of Discretionary Accrual Estimation Models in Earnings Management Research, SSRN Electronic Journal, Electronic copy available at: http://ssrn.com/abstract=1439836, 1-48, DOI: $10.2139 /$ ssrn.1439836

[20] Romney, Marshall B. \& Steinbart, Paul John (2018). Accounting Information Systems. 8th edition, Prentice Hall.

[21] Scott, R. and O'Brien, Patrica (2015). Financial Accounting Theory. Canada: University of Waterloo Queen`s University, 8th edition. ISBN-13: 978-0134166681

[22] Sitanggang, R.P., Karbhari, Y., Matemilola, B.T. and Ariff, M. (2019), "Audit quality and real earnings management: evidence from the UK manufacturing sector", International Journal of Managerial Finance, Vol. 16 No. 2, pp. 165-181. https://doi.org/10.1108/IJMF-03-2018-0095

[23] Susana Callao, José I. Jarne, and David Wróblewski. (2017). "Detecting Earnings Management Investigation on Different Models Measuring Earnings Management for Emerging Eastern European Countries. International Journal of Research Granthaalayah, 5 (11), 222-259. 
https://doi.org/10.29121/granthaalayah.v5.i11 .2017.2351.

[24] Tsai, W., Chen, S., Hwang, E., \& Hsu, J. (2010). A Study of the Impact of Business Process on the ERP System Effectiveness. International Journal of Business and Management, 5(9), 26-37.

[25] Ucakturk, Ahmet and Villard, Michel. (2013), The Effects of Management Information and ERP Systems on Strategic Knowledge Management and DecisionMaking, Procedia social and behavioral, 10351043.

[26] Vasarhelyi, Miklos A; Alles, Michael G. and Kogan, Alexander (2004). Principle of Analytic Monitoring of Continuous Assurance, Journal of Emerging Technologies in Accounting, 1 (1): 1-21, doi.org/10.2308/jeta.2004.1.1.1

[27] Wasiuzzaman, S. (2018), "Industry characteristics and earnings management: a study of Malaysian industries", International Journal of Emerging Markets, Vol. 13 No. 5, pp. 837-854. https://doi.org/10.1108/IJoEM09-2017-0336

[28] Zheng, R. (2019). Is there a difference in relationship between corporate governance and earnings management in different countries? Evidence from comparing the emerging market of China and the developed market of U.S, Unpublished Master Theses. Erasmus School of Economics, UK.

https://www.ase.com.jo

[30] https://www.exchange.jo

\section{Contribution of individual authors to the creation of a scientific article (ghostwriting policy)}

Sulaiman Weshah, Mohammad Elessa and Ayman Shanti formed the study problem and carried out the simulation.

Saqer Al-tahat and Rafat Salameh formed problem solution.

Rafat salameh and Sulaiman Weshah selected the journal, carried out the optimization and prepared the required form.
Mohammad Elessa and Ayman Shanti reviewed the last copy.

\section{Creative Commons Attribution License 4.0 (Attribution 4.0 International, CC BY 4.0)}

This article is published under the terms of the Creative Commons Attribution License 4.0 https://creativecommons.org/licenses/by/4.0/deed.en US 


\section{Appendixes}

Appendix 5: Jordanian (Jo) companies that implement the ERP system in Jordan per sector

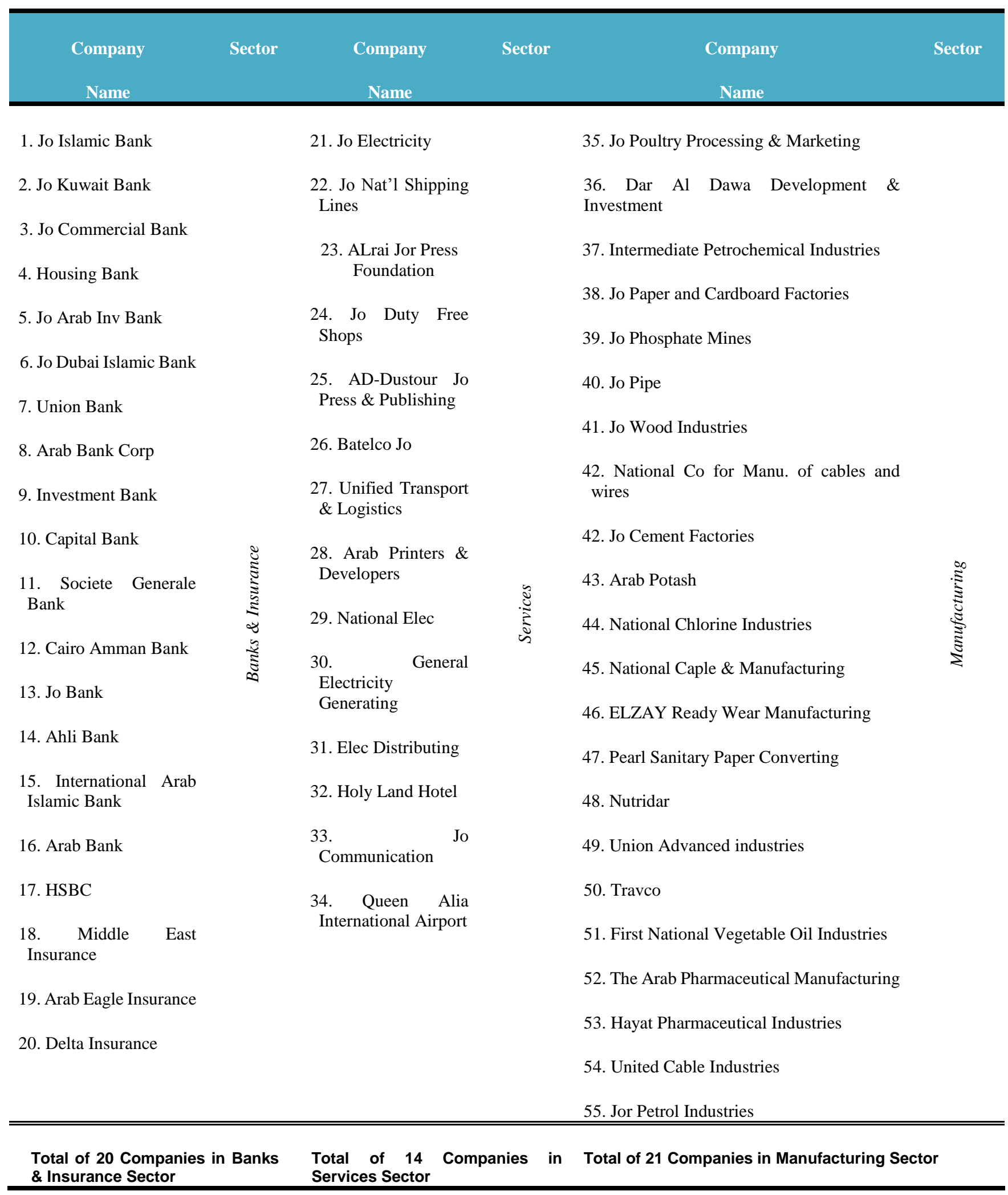

Source: Prepared by Researchers depending on pilot survey. 